\title{
PENGEMBANGAN LKPD TEMATIK-INTEGRATIF BERBASIS KARAKTER PADA PESERTA DIDIK SEKOLAH DASAR
}

\author{
Nurjannah Eka Pradita, Muhammad Nur Wangid \\ Universitas Muhammadiyah Purwokerto, Universitas Negeri Yogyakarta \\ email: dita_zha@yahoo.co.id, nurwangid2003@yahoo.com
}

\begin{abstract}
Abstrak: Penelitian ini bertujuan: 1) menghasilkan LKPD tematik-integratif tema "Tempat Tinggalku" yang layak bagi peserta didik kelas IV SDN 2 Tinggarjaya dan 2) mengetahui efektivitas LKPD tematik-integratif tema "Tempat Tinggalku" pada peserta didik kelas IV SDN 2 Tinggarjaya yang dikembangkan. Penelitian pengembangan ini mengacu pada langkah yang dikembangkan oleh Borg \& Gall. Subjek penelitian adalah peseta didik kelas IV SDN 2 Tinggarjaya. Pengumpulan data menggunakan pedoman wawancara, lembar penilaian produk LKPD, lembar observasi guru, lembar observasi peserta didik, angket respons guru dan angket respons peserta didik, dan angket karakter peserta didik. Analisis data menggunakan teknik analisis deskriptif kuantitatif. Data peningkatan karakter jujur dan peduli dianalisis dengan menggunakan gain standar. Data perbedaan karakter jujur dan peduli dianalisis menggunakan uji t dengan taraf signifikansi 5\%. Hasil penelitian menunjukan bahwa LKPD menurut ahli materi, evaluasi, dan kurikulum ditinjau dari aspek pengintegrasian karakter mendapat skor 4 kategori baik, aspek pedagogi mendapat skor 4,46 kategori sangat baik, konstruksi mendapat skor 4,49 kategori sangat baik dan teknis mendapat skor 4,32 kategori sangat baik sehingga LKPD yang dikembangkan layak digunakan. Pada uji lapangan diperoleh nilai signifikansi gain karakter jujur dan peduli yaitu $0,000<0,05$, sehingga $\mathrm{H}_{0}$ ditolak. Hal ini menunjukkan bahwa terdapat perbedaan yang signifikan rata-rata peningkatan karakter jujur dan peduli.
\end{abstract}

Kata kunci: lembar kerja peserta didik, tematik-integratif, karakter jujur dan peduli.

\section{DEVELOPMENT OF STUDENTS THEMATIC-INTEGRATIVE ACTIVITY SHEET BASED ON CHARACTER IN CLASS IV SDN 2 TINGGARJAYA}

Abstract: This study aims to: (1) develop a thematic student activity sheet on the theme "Where I Live" suitable for fourth grade students of Public Elementary School 2 Tinggarjaya, and (2) determine the effectiveness of thematic-integrative student activity sheet grade students Public Elementary School 2 Tinggarjaya developed. This study refers to the development and research developed by Borg \& Gall that includes. Subject research fourth grade students of SDN 2 Tinggarjaya. Collecting data used interview guides, product assessment student activity sheet, teacher observation sheets, observation sheets of learners, the teacher questionnaire responsses and questionnaire responsses of learners. Mechanical analysis using quantitative descriptive analysis techniques. Data enhancement honest and caring character were analyzed using gain standard. Data honest and caring character differences were analyzed using t test with a significance level of 5\%. The results show that the material student activity sheet according to experts, evaluation, curriculum and teachers in terms of aspects of integrating character got good score of 4 categories, aspects of Pedagogy got a very good score of 4.46 category, construction got a score of 4.49 excellent and the technical category got a score of 4,32 categories very well developed so student activity sheet fit for use. In the field tests it is obtained a significance value gain honest and caring character as much as $0.000<0.05$, so $\mathrm{H}_{0}$ is rejected. This shows that there are significant differences on average increase of the character honest and caring

Keywords: worksheet learners (LKPD), thematic-integrative, creative character and hard work. 


\section{PENDAHULUAN}

Pendidikan merupakan suatu hal yang sangat penting bagi kehidupan suatu bangsa. Pendidikan merupakan upaya meningkatkan kualitas sumber daya manusia. Pendidikan adalah suatu cara untuk menghasilkan masyarakat menjadi insan yang cerdas, terampil, berkarakter, dan juga bermartabat. Oleh sebab itu, kemajuan suatu bangsa dapat dilihat dari kualitas sumber daya manusianya. Pendidikan berpengaruh besar bagi perkembangan kualitas sumber daya manusia. Keterlibatan pemerintah dan masyarakat sangat diperlukan dalam rangka mencapai tujuan pendidikan seperti yang tertuang dalam Undang-Undang Nomor 20 Tahun 2003 tentang Sistem Pendidikan Nasional Bab II Pasal 3 yang menyebutkan bahwa pendidikan nasional berfungsi mengembangkan kemampuan dan membentuk watak serta peradaban bangsa yang bermartabat dalam rangka mencerdaskan kehidupan bangsa, bertujuan untuk berkembangnya potensi peserta didik agar menjadi manusia yang beriman dan bertakwa kepada Tuhan Yang Maha Esa, berakhlak mulia, sehat, berilmu, cakap, kreatif, mandiri, dan menjadi warga negara yang demokratis serta bertanggung jawab.

Untuk mewujudkan tujuan pendidikan tersebut, pemerintah berupaya mencerdaskan kehidupan bangsa dan mengembangkan manusia Indonesia seutuhnya, yaitu manusia yang beriman dan bertakwa terhadap Tuhan Yang Maha Esa, berbudi pekerti luhur, memiliki pengetahuan dan keterampilan, sehat jasmani dan rohani, berkepribadian yang mantap dan mandiri, serta rasa tanggung jawab kemasyarakatan dan kebangsaan. Untuk mencapai tujuan pendidikan nasional, banyak komponen yang saling berkaitan dalam sistem pendidikan nasional itu sendiri salah satunya adalah kurikulum.

Dalam rangka mewujudkan tujuan pendidikan nasional untuk meningkatkan kualitas dan kuantitas sumber daya manusia Indonesia, pemerintah mencanangkan kurikulum baru yaitu Kurikulum 2013 sebagai penyempurnaan kurikulum sebelumnya, yaitu Kurikulum Tingkat Satuan Pendidikan (KTSP).

Kurikulum 2013 ini diuji coba penerapannya pada tahun pelajaran 2013/2014 di sekolah dasar untuk kelas I dan IV dan SMP kelas VII. Terkait mata pelajaran, versi Kurikulum 2013 mengalami penggabungan mata pelajaran di Sekolah Dasar (SD). Mata pelajaran tersebut adalah mata pelajaran Ilmu Pengetahuan Alam (IPA) dan Ilmu Pengetahuan Sosial (IPS) ke dalam mata pelajaran Bahasa Indonesia. Berdasarkan versi tersebut, pelaksanaan Kurikulum 2013 dimulai tahun pelajaran 2013/2014 dan untuk SD, jumlah mata pelajaran diringkas menjadi tujuh yaitu Pendidikan Agama, Pendidikan Pancasila dan Kewarganegaraan, Bahasa Indonesia, matematika, Seni Budaya dan Prakarya, Pendidikan Jasmani, Olahraga dan Kesehatan, serta Pramuka.

Poerwati \& Sofan (2013: 286) menyatakan dalam bukunya yang berjudul Kurikulum 2013 bahwa Kurikulum 2013 menganut pembentukan pembelajaran yang ideal yaitu pembelajaran peserta didik aktif dan kritis, peserta didik tidak kosong melainkan sudah ada pengertian awal tertentu yang dibantu untuk berkembang. Hal ini menunjukan bahwa Kurikulum 2013 memandang pengembangan sikap menjadi salah satu hal yang ditekankan karena peserta didik akan menjadi generasi penerus bangsa yang diharapkan memiliki pribadi-pribadi yang berkarakter. Oleh karena itu, model pembelajaran tematik-integratif perlu dicanangkan dalam Kurikulum 2013. Pentingnya pembelajaran tematik-integratif diterapkan di sekolah dasar berdasarkan pendapat Rusman (2011: 257) karena pada umumnya peserta didik pada tahap ini masih melihat segala sesuatu sebagai satu keutuhan (holistik), perkembangan fisiknya tidak pernah bisa dipisahkan dengan perkembangan mental, sosial, dan emosionalnya. Pelaksanaan pembentukan pembelajaran yang ideal dalam Kurikulum 2013 juga didasari sejak lama oleh pendapat Lickona (1991: 6) yang mengatakan, "Down through history, in countries all over the world, education has had two great goals: to help young people become smart and to help them become good".

Dari pengertian di atas dapat diartikan bahwa pendidikan merupakan sarana yang dapat memberikan kontribusi besar dalam membangun karakter dan memajukan masyarakat suatu bangsa untuk melakukan perubahan-perubahan ke arah yang positif. Sebuah bangsa akan maju atau mundur bergantung pada kualitas pendidikan yang dimiliki oleh suatu negara. Dengan demikian, pendidikan mempunyai peran penting dalam membentuk karakter suatu bangsa. 
$\begin{array}{ccr}\text { Pendidikan } & \text { tidak sekadar } \\ \text { mengembangkan aspek kognitif dan }\end{array}$ psikomotorik saja, namun aspek afektif dan kepribadian sebagai pondasi para peserta didik dalam memperoleh aspek kognitif dan psikomotorik juga harus dikembangkan. Kepintaran kognitif dan psikomotorik tanpa diimbangi oleh aspek afektif dan kepribadian yang baik akan sulit diterima di masyarakat. Kompetensi inti harus menggambarkan kualitas yang seimbang antara pencapaian hard skill dan soft skill (Kemendikbud, 2013: 5). Sekitar 20\% kesuksesan ditentukan oleh hard skill dan selebihnya $80 \%$ oleh soft skill. Hal ini menyiratkan bahwa karakter yang baik harus dimiliki oleh setiap peserta didik. Faktor pendidikan, faktor keluarga, faktor masyarakat atau lingkungan, faktor media, dan lainnya sangat memengaruhi perilaku dan kepribadian para peserta didik.

Kondisi di lapangan diketahui bahwa bahwa moralitas dan kepedulian anak-anak terhadap nilai-nilai sosial semakin menurun sehingga sikap mereka kepada sesama dan lingkungan teman mereka semakin luntur. Seperti berita pada Tempo.co Selasa, 20 Mei 2014 melangsir bahwa masih banyak peserta didik SD di kawasan Srengseng Jakarta Barat mengaku sudah memegang kunci jawaban soal Ujian Nasional dan peserta didik lainnya mengakui mencontek saat mengerjakan soal Ujian Nasional berlangsung. Ditambah lagi dengan adanya berita video kekerasan peserta didik SD di jejaring sosial seperti yang diberitakan di Padangtoday.com 12 Oktober 2014.

Alternatif untuk mengatasi masalahmasalah tersebut yaitu menggunakan pendidikan karakter yang diintegrasikan ke dalam pembelajaran tematik-integratif berbasis karakter. Suharjana (2012: 190) mengatakan bahwa pendidikan karakter dapat diupayakan melalui berbagai media, baik melalui jalur pendidikan formal di sekolah, pendidikan nonformal di masyarakat maupun di dalam keluarga, maupun melalui jalur pendidikan agama maupun jalur pendidikan yang lain.

Kurikulum 2013 merupakan upaya pemerintah untuk mengatasi persoalan yang sedang dialami oleh para peserta didik di Indonesia. Munculnya kurikulum 2013 adalah hal yang tepat karena dalam kurikulum tersebut mengintegrasian nilai-nilai karakter dalam pembelajaran. Dalam pembelajaran, guru dapat mengintegrasikan tradisi agama dan ilmu pengetahuan modern ke dalam pembelajaran tematik. Pembelajaran tematik-integratif dan pendidikan karakter dikemas dalam satu kesatuan paradigma yang utuh dalam kurikulum 2013.

Banyak manfaat yang dapat diperoleh dengan diberlakukannya kurikulum 2013. Manfaat Kurikulum 2013 yang disebutkan oleh Poerwati \& Sofan (2013: 284-286) yaitu (1) bagi sekolah, Kurikulum 2013 memberikan otonomi sekaligus tanggung jawab kepada sekolah untuk mengembangkan kurikulum sesuai kondisi dan kebutuhan sekolah; (2) bagi guru, adanya perubahan paradigma mengajar yaitu guru sebagai fasilitator dalam membantu peserta didik membangun pengetahuan; dan (3) bagi peserta didik, Kurikulum 2013 membuat peserta didik lebih mudah mengikuti pembelajaran karena diberi kebebasan untuk mengembangkan kompetensi dengan kultur daerahnya. Berdasarkan manfaat Kurikulum 2013 bagi sekolah, guru, dan peserta didik, sekolah bertanggung jawab dalam mengembangkan kurikulum bagi sekolahnya dan guru dituntut dapat mengembangkan bahan ajar yang digunakan dalam pembelajaran.

Berdasarkan hasil wawancara dengan guru kelas IV di SD Negeri 2 Tinggarjaya diperoleh informasi bahwa dalam menyongsong implementasi Kurikulum 2013, kita perlu melakukan persiapan yang matang terutama kelengkapan perangkat pembelajaran. Beberapa sudah disediakan oleh pemerintah, namun beberapa yang lain belum disediakan. Hal ini menuntut pihak sekolah harus menyiapkan yang lain seperti RPP dan LKPD yang mencerminkan pendidikan karakter untuk mempermudah proses pembelajaran. Sekolah tersebut belum memiliki dan atau menyediakan LKPD tematik-integratif berbasis karakter untuk menunjang pembelajaran Kurikulum 2013, sedangkan guru sendiri kesulitan untuk mengembangkan LKPD yang sesuai dengan Kurikulum 2013 berbasis karakter. Sekolah sangat membutuhkan adanya LKPD tematikintegratif berbasis karakter terutama karakter jujur dan peduli dikarenakan peserta didik masih memiliki rasa kejujuran dan kepedulian yang rendah, seperti masih kurangnya kepedulian peserta didik membuang sampah jajan di tempat sampah saat jam istirahat dan 
masih kurangnya kesadaran bersikap jujur ketika sedang mengikuti ulangan.

Untuk menyukseskan pelaksanaan Kurikulum 2013, pemerintah telah menyediakan silabus, buku pedoman guru dan peserta didik, serta jaringan tema. Namun demikian, perangkat pembelajaran lainnya seperti LKPD harus disiapkan oleh para guru, sementara para guru masih kesulitan melakukan pengadaaan LKPD tematik-integratif yang berbasis karakter jujur dan peduli yang dinilai sangat penting untuk menunjang pembelajaran Kurikulum 2013 dan membudayakan sikap kepedulian dan kejujuran peserta didik. Untuk itu, perlu adanya pengembangan Lembar Kerja Peserta Didik (LKPD) sebagai bahan ajar yang sesuai dengan Kurikulum 2013. Berdasarkan hal tersebut, penelitian ini bertujuan untuk menghasilkan LKPD tematik-integratif berbasis karakter di SD. Bahan ajar yang dimaksud adalah LKPD pembelajaran yang dapat digunakan sebagai acuan baik oleh peserta didik maupun pendidik. Oleh karena itu, pembatasan masalah dalam penelitian ini yaitu belum tersedianya perangkat pembelajaran LKPD tematik-integratif penunjang pelaksanaan pembelajaran tematik-integratif yang terintegrasi karakter jujur dan peduli pada kelas IV SD N 2 Tinggarjaya.

Penelitian dan pengembangan ini difokuskan pada dua permasalahan, yaitu LKPD tematik-integratif yang layak untuk mengembangkan karakter jujur dan peduli di kelas IV SDN 2 Tinggarjaya dan efektivitas LKPD tematik-integratif dalam mengembangkan karakter jujur dan peduli bagi kelas IV SDN 2 Tinggarjaya. Selaras dengan rumusan masalah tersebut, penelitian dan pengembangan ini bertujuan untuk menghasilkan LKPD tematik-integratif berbasisai karakter yang layak untuk peserta didik kelas IV SDN 2 Tinggarjaya. Di samping itu, penelitian dan pengembangan ini juga bertujuan mengetahui efektivitas LKPD tematik-integratif berbasis nilai karakter pada peserta didik kelas IV SDN 2 Tinggarjaya. Hasil dari penelitian ini diharapkan mampu memberikan informasi ilmiah terkait pengembangan LKPD tematik-integratif berbasis karakter dan sebagai bahan masukan untuk pengembangan pengetahuan.

\section{METODE}

\section{Jenis Penelitian}

Jenis penelitian ini adalah penelitian dan pengembangan (Research and Development). Model pengembangan dalam penelitian dan pengembangan ini mengikuti desain dari Borg \& Gall (1983: 775) yang terdiri atas 10 langkah. Langkah-langkah itu sebagai berikut: (1) mengumpulkan informasi dan melakukan penelitian awal (research and information collecting; (2) perencanaan (planning); (3) pengembangan draf produk awal (developing preliminary form of product); (4) uji coba awal (preliminary field testing); (5) revisi terhadap hasil uji coba (main product revision); (6) uji coba lapangan (main field testing); (7) revisi produk hasil uji coba lapangan (operational product revision); (8) uji pelaksanaan lapangan (operational field testing); (9) revisi produk akhir (final product revision), dan (10) diseminasi dan implementasi (dissemination and implementation). Produk yang dikembangkan adalah LKPD. Pada bulan pertama dilakukan studi pendahuluan dan pengembangan produk yang berupa LKPD. Pada bulan kedua dilakukan uji coba produk LKPD di SD. Bulan ketiga melakukan evaluasi revisi dan finalisasi LKPD di SD.

\section{Prosedur Pengembangan}

Prosedur penelitian dan pengembangan pada dasarnya terdiri atas dua tujuan utama, yaitu (1) pengembangan produk, dan (2) menguji keefektifan produk dalam mencapai tujuan. Penelitian ini mengambil sembilan langkah dari model Borg \& Gall (1983: 775), yaitu sebagai berikut.

\section{Studi Pendahuluan dan Pengumpulan Data}

Pada tahap penelitian pendahuluan yang dilakukan adalah studi pustaka dan survei lapangan. Studi pustaka dilakukan untuk mendapatkan informasi pengetahuan tentang pembelajaran tematik-integratif yang membutuhkan bahan ajar LKPD yang terintegrasi dengan karakter jujur dan peduli. Survei lapangan dilakukan dengan tujuan untuk mengumpulkan informasi yang relevan yang diperlukan dalam pengembangan LKPD tematik-integratif berbasis karakter. Di samping itu, survei lapangan dilakukan untuk mengumpulkan informasi mengenai Kurikulum 2013, LKPD yang digunakan oleh guru, strategi pembelajaran yang digunakan, bahan ajar yang 
digunakan, metode pembelajaran, dan sistem evaluasi yang diterapkan untuk mengetahui ketercapaian pendidikan karakter peserta didik, dan masukan dari guru.

\section{Perencanaan}

Tahap perencanaan penelitian ini meliputi langkah awal yaitu perumusan tujuan pembelajaran untuk mengetahui proses pembelajaran yang akan dilakukan dan keberhasilan pembelajaran yang dilakukan, sehingga diperlukan perumusan indikatorindikator dalam pembelajaran tematik-integratif untuk kelas IV SD Negeri 2 Tinggarjaya, membatasi masalah penelitian dan mempelajari ketersesuaian pembelajaran dengan Kurikulum 2013 yang berlaku, dan melakukan observasi awal di SD Negeri 2 Tinggarjaya dan wawancara dengan guru SD sekolah tersebut. Pada tahap ini peneliti mulai menetapkan rancangan pengembangan produk. Hal yang direncanakan antara lain: pengembangan LKPD tematik-integratif berbasis karakter yang efektif dan efisien. LKPD dirancang dengan unsur pengintegrasian karakter, pedagogik, konstruksi, dan teknis.

\section{Produk Awal}

Penyusunan produk awal LKPD pembelajaran tematik-integratif berbasis karakter akan menghasilkan produk LKPD yang di dalamnya mencakup: Persyaratan pedagogik yaitu: (1) penemuan konsep, (2) petunjuk belajar, (3) kompetensi yang akan dicapai, (4) informasi pendukung, (5) petunjuk kerja atau lembar kerja, (7) kegiatan peserta didik, (8) penguatan karakter, dan (9) kerja sama dengan orang tua. Persyaratan konstruksi, LKPD di dalamnya memuat bahasa yang sesuai dengan tingkat perkembangan peserta didik yaitu: (1) struktur kalimat yang sederhana, pendek, jelas, dan tidak berbelit-belit, (2) sistematika yang baik, (3) tujuan belajar, (4) memuat identitas LKPD, (5) sesuai karakteristik peserta didik, (6) digunakan menurut waktu dan tempat yang dipilih, (7) membuat peserta didik aktif, (8) keakuratan isi, (9) kebenaran konsep, dan (10) kebenaran istilah. Persyaratan teknis LKPD berupa: (1) tulisan, (2) gambar (3) Cover, (4) topik, (5) ukuran, (6) kepadatan halaman, (7) penomoran, dan (8) kejelasan. Penyusunan LKPD awal dimasukkan di dalam forum guru kelas IV SD Negeri 2 Tinggarjaya untuk dimintai saran mengenai LKPD tematik-integratif yang dikembangkan. Setelah dilakukan perbaikan berdasarkan saran para guru di dalam forum diskusi guru kelas IV SD Negeri 2 Tinggarjaya produk awal LKPD tematik-integratif berbasis karakter jujur dan peduli dibuat. LKPD awal yang telah dikembangkan, sebelum diujicobakan pada kelompok kecil di SD Negeri 2 Tinggarjaya, divalidasi terlebih dahulu oleh ahli materi, karakter, dan evaluasi.

\section{Uji Coba Awal}

Uji coba awal produk LKPD tematikintegratif berbasis karakter dilakukan di SD Negeri 2 Tinggarjaya dengan subyek 10 peserta didik dengan metode eksperimen single one shot case study. Hasil uji coba kelompok kecil dijadikan sebagai landasan perbaikan produk LKPD tematik-integratif berbasis karakter yang nantinya diujicobakan pada subjek yang lebih luas.

\section{Revisi Produk Uji Coba Awal}

Pada tahap ini dilakukan proses revisi berdasarkan analisis kebutuhan uji coba pada kelompok kecil. Kemudian disusun LKPD dengan berpedoman pada kriteria penyusunan LKPD pembelajaran tematik-integratif berbasis karakter. Selanjutnya LKPD diujicobakan kepada peserta didik pada uji lapangan.

\section{Uji Coba Lapangan}

Uji coba lapangan melibatkan subjek lebih luas yaitu 32 peserta didik kelas IV yang dilakukan dengan metode eksperimen one group pretest-posttes. Dilakukan analisis data berdasarkan angket penilaian peserta didik terhadap LKPD, observasi penggunaan LKPD, observasi karakter jujur dan peduli. Pada tahap ini digunakan pretest untuk membandingkan keadaan sebelum diberi perlakuan dan posttest sesudah diberi perlakuan agar lebih akurat dengan menggunakan lembar observasi karakter awal dan akhir.

\section{Revisi Produk Uji Coba lapangan}

Pada tahap ini dilakukan proses revisi LKPD tematik-integratif berbasis karakter berdasarkan kekurangan dan kelemahan yang diketahui setelah uji coba lapangan. Kemudian disusun LKPD yang nantinya akan diujicobakan pada uji lapangan.

\section{Uji Lapangan}

Selanjutnya dilakukan uji lapangan dengan melibatkan subjek yang lebih luas yaitu 2 kelas dengan jumlah 74 peserta didik kelas IV A dan B. Uji coba menggunakan kelas 
eksperimen dan kelas kontrol. Uji lapangan dilakukan dengan metode Quasi Experimental Design menggunakan desain Nonequivalent Control Group Design. Uji coba lapangan, dimaksudkan untuk menguji keterlaksanaan produk akhir LKPD dan mengetahui hasil penerapan LKPD tematik-integratif berbasis karakter yaitu penilaian karakter setelah menggunakan LKPD tematik-integratif berbasis karakter di kelas IVB.

\section{Revisi Produk Akhir}

Setelah mendapat masukan dari forum guru kelas IV SD Negeri 2 Tinggarjaya, penilaian para ahli, respons peserta didik mulai dari uji coba kelompok kecil, uji coba lapangan, dan uji lapangan, LKPD kembali direvisi untuk disempurnakan menjadi produk akhir yaitu LKPD tematik-integratif tema "Tempat Tinggalku" berbasis karakter jujur dan peduli untuk peserta didik kelas IV SD Negeri 2 Tinggarjaya.

\section{Desain Uji Coba}

Uji coba produk bertujuan untuk menyempurnakan produk LKPD dengan mempraktikkannya secara langsung di lapangan. Uji coba LKPD dilakukan melalui tahap: (1) produk awal (validasi ahli materi, karakter dan evaluasi), (2) uji coba awal (uji coba kelompok kecil dengan metode single one shot study), (3) uji coba lapangan (uji coba lapangan dengan metode one group pretestpostte), dan (4) uji lapangan (uji lapangan dengan metode Quasi eksperime).

\section{Subjek Coba}

Subjek coba dalam penelitian adalah peserta didik kelas IV SDN 2 Tinggarjaya. Subjek uji coba kelompok kecil di kelas IVA berjumlah 10 peserta didik. Subjek uji coba lapangan di kelas IVC berjumlah 32 peserta didik. Uji lapangan menggunakan kelas IVA sebagai kelas kontrol berjumlah 37 peserta didik dan IVB sebagai kelas eksperimen berjumlah 37 peserta didik.

\section{Teknik Pengumpulan Data}

Ada empat teknik yang digunakan dalam pengumpulan data, yaitu penilaian produk, observasi, wawancara, dan angket. Instrumen penelitiannya adalah pedoman pedoman penilaian produk, pedoman observasi, pedoman wawancara, dan lembar angket)

\section{Teknik Analisis Data}

Teknik analisis data yang digunakan adalah analisis data deskriptif kuantitatif yang dilakukan untuk menganalisis data hasil observasi. Kualitas draf LKPD disusun dan dianalisis oleh para ahli materi, ahli karakter dan ahli evaluasi sebelum pelaksanaan uji coba awal, uji coba lapangan, dan uji lapangan. Berdasarkan ketiga hasil uji coba diperoleh sejumlah data kuantitatif. Data tersebut kemudian dianalisis untuk memperoleh produk penelitian akhir yang diharapkan, yaitu berupa LKPD tematik-integratif berbasis karakter jujur dan peduli untuk kelas IV SD Negeri 2 Tinggarjaya.

\section{Analisi Data Kelayakan Produk LKPD}

Langkah-langkah analisis data kelayakan LKPD tematik-integratif berbasis karakter untuk kelas IV Sekolah Dasar sebagai berikut: mengubah penilaian dalam bentuk kualitatif menjadi kuantitatif dengan ketentuan skor 5 untuk kriteria sangat baik, skor 4 untuk kriteria baik, skor 3 untuk kriteria cukup, skor 2 untuk kriteria kurang, dan skor 1 untuk kriteria sangat kurang. Hasil penilaian terhadap itemitem observasi yang terkumpul dihitung skor rata-ratanya. Selanjutnya skor rata-rata dikonversi menjadi nilai kualitatif dengan kriteria penilaian yang akan dipaparkan berikut ini (Azwar, 2010: 163).

Tabel 1. Konversi Skor Nilai Skala 5

\begin{tabular}{ccc}
\hline Nilai & Rentang Skor & Kategori \\
\hline A & $\mathrm{X}>(\mathrm{M}+1,50 \mathrm{~s})$ & $\begin{array}{c}\text { Sangat } \\
\text { Baik }\end{array}$ \\
B & $(\mathrm{M}+0,50 \mathrm{~s})<\mathrm{X} \leq$ & Baik \\
& $(\mathrm{M}+1,50)$ & \\
C & $(\mathrm{M}-0,50 \mathrm{~s})<\mathrm{X} \leq$ & Cukup \\
& $(\mathrm{M}+0,50 \mathrm{~s})$ & \\
D & $(\mathrm{M}-1,50 \mathrm{~s})<\mathrm{X} \leq$ & Kurang \\
& $(\mathrm{M}-0,50 \mathrm{~s})$ & Sangat \\
E & $\mathrm{X} \leq(\mathrm{M}-1,50 \mathrm{~s})$ & Kurang \\
\hline
\end{tabular}

Keterangan:

$\mathrm{X}=$ skor rata-rata

$\mathrm{M}=$ rata-rata ideal

$\mathrm{s}=$ simpangan baku

Kriteria kelayakan terendah penelitian ini adalah nilai minimal $\mathrm{C}$ dengan kategori cukup. Jadi, jika hasil penilaian reratanya menunjukkan hasil akhir $\mathrm{C}$, maka produk LKPD tematik-integratif berbasis karakter di SD Negeri 2 Tinggarjaya dapat dianggap layak digunakan.

Analisis Respons peserta didik 
Analisis ini dilakukan dengan cara menghitung rata-rata skor yang diberikan oleh peserta didik. Rata-rata skor yang diberikan oleh peserta didik tersebut kemudian dikonversi menjadi skala empat. Adapun acuan penafsiran skor ke dalam skala empat adalah sebagai berikut (Kemendiknas, 2010: 60).

Tabel 2. Konversi Skor Menjadi Nilai Skala 4

\begin{tabular}{|c|c|c|}
\hline Rentang Skor & Nilai & Kategori \\
\hline $\begin{array}{c}x+1,5 . S D \leq \\
x i \geq x+3,0 . S D\end{array}$ & $\mathrm{~A}$ & Sangat Baik \\
\hline $\begin{array}{c}x+0 . S D \leq x i \geq \\
x+1,5 . S D\end{array}$ & B & Baik \\
\hline $\begin{array}{c}x-1,5 . S D \leq x i \geq \\
x+0 . S D\end{array}$ & $\mathrm{C}$ & Kurang Baik \\
\hline $\begin{array}{c}x-3,0 . S D \leq x i \geq \\
x-1,5 . S D\end{array}$ & $\mathrm{D}$ & $\begin{array}{c}\text { Sangat Kurang } \\
\text { Baik }\end{array}$ \\
\hline
\end{tabular}

\section{Analisis Data Keterlaksanaan Pembelajaran}

Data keterlaksanaan pembelajaran dianalisis dengan cara menghitung rata-rata skor yang diberikan oleh observer dan menghitung persentasi keterlaksanaan pembelajaran. Perhitungan persentase keterlaksanaan pembelajarn dihitung dengan menggunakan program Microsoft Office Excel.

\section{Analisis Peningkatan Karakter Jujur dan Peduli}

Untuk menentukan pengaruh LKPD tematik-integratif dilihat dari hasil pre-test dan post-test melalui hasil observasi karakter siswa. Rating scale karakter kejujuran dan kepedulian yang diisi oleh observer menghasilkan rata-rata skor yang akan dianalils. Rata-rata skor yang dihasilkan akan dikonversikan menjadi skala empat. Acuan penafsiran skor ke dalam skala empat seperti berikut ini (diadaptasi dari Kemendiknas, 2010: 60)

Tabel 3. Kategorisasi Karakter Peserta didik

\begin{tabular}{|c|c|c|}
\hline $\begin{array}{c}\text { Rentang } \\
\text { Skor }\end{array}$ & Nilai & Kategori \\
\hline $\begin{array}{c}\overline{\bar{x}}+1,5 S B i \leq \mathrm{X} \\
\geq \bar{x}+3,0 S b i\end{array}$ & A & $\begin{array}{c}\text { Sudah Membudaya } \\
\text { (SM) }\end{array}$ \\
\hline $\begin{array}{c}\overline{\bar{x}}+0 . S B i \leq \mathrm{X} \\
<\bar{x}+1,5 S b i\end{array}$ & B & $\begin{array}{c}\text { Mulai Berkembang } \\
\text { (MB) }\end{array}$ \\
\hline $\begin{array}{c}\bar{x}-1,5 S B i \leq \mathrm{X} \\
<\bar{x}+0 . S b i\end{array}$ & $\mathrm{C}$ & $\begin{array}{l}\text { Mulai Terlihat } \\
\text { (MT) }\end{array}$ \\
\hline $\begin{array}{c}\bar{x}-3,0 S B i \leq \mathrm{X} \\
<\bar{x}-1,5 S b i\end{array}$ & D & $\begin{array}{c}\text { Belum Terlihat } \\
\text { (BT) }\end{array}$ \\
\hline
\end{tabular}

Keterangan:

$\mathrm{x}=$ skor yang dicapai $\bar{x}=$ rerata skor ideal $=(1 / 2)$ (skor tertinggi ideal + skor terendah ideal).

$S B i=(1 / 6)$ (skor tertinggi ideal - skor terendah ideal)

Analisis peningkatan karakter Peserta didik dengan menggunakan gain standar. Pada kenyataannya menaikkan skor peserta didik yang sudah tinggi lebih sulit daripada menaikkan skor peserta didik yang masih rendah. Di lapangan sering dijumpai terjadinya kesalahan dalam menentukan peserta didik mana yang kenaikan skornya lebih tinggi. Oleh karena itu, dalam penelitian ini teknik gain standart lebih tepat untuk digunakan. Gain standart dihitung dengan persamaan berikut (Bao, 2006: 917)

Gain Sandart $=\frac{\text { Posttest }- \text { prettest }}{\text { Max Skor }- \text { pretest }}$

\section{Analisis Perbedaan Karakter Jujur dan Peduli}

Data yang akan dianalisis dalam penelitian ini adalah gain standard karakter jujur dan peduli. Analisis dilakukan untuk mengetahui perbedaan peningkatan karakter jujur dan peduli pada kelas eksperimen dan kelas kontrol. Uji prasyarat yang harus dipenuhi sebelum uji $\mathrm{t}$ adalah uji normalitas dan uji homogenitas. Uji normalitas dilakukan untuk mengetahui apakah data dari masing-masing variabel berdistribusi normal atau tidak. Uji normalitas dilakukan terhadap gain standart karakter jujur dan peduli. Uji normalitas dilakukan menggunakan uji kolmogrorovsmirnov. Uji homogenitas bertujuan untuk mengetahui apakah data pada kelompok eksperimen dan kelompok kontrol mempunyai varians yang sama atau tidak. Uji homogenitas varians dilakukan terhadap data gain standard karakter jujur dan peduli. Uji homogenitas varians gain karakter jujur dan peduli dilakukan menggunakan uji Levene dengan taraf signifikansi $5 \%$.

\section{HASIL DAN PEMBAHASAN}

\section{Hasil Kelayakan Produk}

Hasil kelayakan produk merupakan hasil kelayakan yang telah dinilai oleh ahli materi, ahli kurikulum, dan ahli evaluasi. Validasi terhadap kelayakan pruduk, meliputi penilaian dari aspek pengintegrasian karakter, aspek pedagogik, aspek konstruksi, dan aspek 
teknis LKPD tematik-integratif berbasis karakter.

\section{Hasil validasi LKPD tematik-integratif berbasis karakter}

Produk yang dikembangkan dalam penelitian ini berupa LKPD tematik-integratif berbasis karakter dengan tema "Tempat Tinggalku".. Produk yang berupa LKPD ini telah divalidasi oleh beberapa ahli. Data hasil validasi LKPD tematik integratif berbasis karakter meliputi data hasil penilaian oleh ahli materi, ahli kurikulum, dan ahli evaluasi. Data ini berupa skor penilaian dan masukan terhadap produk LKPD tematik-integratif berbasis karakter yang dikembangkan.

Tabel 4. Hasil validasi LKPD

\begin{tabular}{lll}
\hline \multicolumn{1}{c}{ Aspek } & Nilai & \multicolumn{1}{c}{ Kategori } \\
\hline $\begin{array}{l}\text { Pengintegrasian } \\
\text { karakter }\end{array}$ & 4 & Baik \\
Pedagogik & 4,4 & Sangat baik \\
Konstruksi & 4,5 & Sangat baik \\
Teknis & 4,3 & Sangat baik \\
Rata-rata & 4,3 & Sangat baik \\
\hline
\end{tabular}

Validasi yang dilakukan oleh ahli materi, ahli kurikulum, dan ahli evaluasi, memberi hasil penilaian terhadap LKPD tematik-integratif aspek pengintegrasian karakter jujur dan peduli dengan skor 4 yang dikategorikan baik. Artinya pengembangan LKPD tematik-integratif dari segi aspek pengintegrasian karakter jujur dan peduli sudah baik. Hasil validasi LKPD tematik-integratif untuk aspek pedagogi yakni 4,4 dengan kriteria "sangat baik". Artinya pengembangan LKPD tematik-integratif untuk aspek pedagogik sangat baik.

Hasil validasi LKPD tematik-integratif untuk aspek konstruksi yakni 4,49 dengan kriteria "sangat baik". Artinya pengembangan LKPD tematik-integratif untuk aspek konstruksi dari ahli materi dan ahli kurikulum memberi penilaian dengan kategori sangat baik. Hasil validasi LKPD tematik-integratif untuk aspek konstruksi yakni 4,29 dengan kriteria "sangat baik". Berdasarkan penilaian di atas dapat disimpulkan bahwa pengembangan LKPD tematik-integratif dari ahli materi dan ahli kurikulum memberi penilaian sangat baik sehingga LKPD layak untuk dilakukan uji coba lapangan di SD Negeri 2 Tinggarjaya.
Hasil Observasi Awal dan Akhir Karakter Jujur dan Peduli

Uji coba lapangan dilakukan untuk mengetahui kendala operasional penggunaan LKPD tematik-integratif yang telah dikembangkan. Uji coba lapangan dilakukan di kelas IV A SD Negeri 2 Tinggarjaya dengan jumlah peserta didik 32 orang. Hasil observasi awal dan akhir karakter jujur dan peduli dengan tema "Tempat Tinggalku" dapat dilihat pada rekapitulasi hasil observasi tabel berikut.

Tabel 5. Hasil observasi awal dan akhir karakter jujur dan peduli pada uji coba lapangan

\begin{tabular}{lll}
\hline Kriteria & $\begin{array}{l}\text { Observasi } \\
\text { Awal }\end{array}$ & $\begin{array}{l}\text { Observasi } \\
\text { Akhir }\end{array}$ \\
\hline Rata-rata & 60,35 & 70,1 \\
S. Deviasi & 5,52 & 4,63 \\
Maksimum & 69 & 81 \\
Minimum & 50 & 62 \\
\hline
\end{tabular}

Berdasarkan hasil observasi awal dan akhir karakter jujur dan peduli terlihat bahwa rata-rata karakter setelah mengikuti pembelajaran dengan menggunakan LKPD tematik-integratif lebih baik daripada sebelumnya.

\section{Uji Normalitas}

Uji normalitas dilakukan dengan menggunakan uji Kolmogorov-Smirnov dengan taraf signifikansi 0,05. Hasil uji normalitas data karakter jujur dan peduli ditunjukkan pada tabel berikut.

Tabel 6. Hasil uji normalitas data karakter jujur dan peduli pada uji coba lapangan

\begin{tabular}{lllll}
\hline \multirow{2}{*}{ Karakter } & \multirow{2}{*}{ Obesrvasi } & \multicolumn{3}{l}{ Kolmogorov-Smirnov } \\
\cline { 3 - 5 } & & Statistic & df & Sig. \\
\hline \multirow{2}{*}{ Jujur dan Awal } & 0,131 & 32 & 0,172 \\
Peduli & Akhir & 0,122 & 32 & $0,200^{*}$ \\
\hline
\end{tabular}

Berdasarkan hasil uji normalitas pada Tabel 6 terlihat bahwa nilai signifikansi data awal karakter jujur dan peduli yaitu 0,172 > 0,05, sehingga $\mathrm{H}_{0}$ diterima. Hal ini menunjukkan bahwa data awal karakter jujur dan peduli berdistribusi normal. Nilai signifikansi data akhir karakter jujur dan peduli 0,200>0,05, sehingga $\mathrm{H}_{0}$ diterima. Hal ini menunjukkan bahwa data akhir karakter jujur dan peduli berdistribusi normal.

\section{Uji t Sampel Berpasangan}


Uji t sampel berpasangan digunakan untuk mengetahui perbedaan rata-rata sebelum dan sesudah mengikuti pembelajaran menggunakan LKPD tematik-integratif berbasis karakter dengan tema "Tempat Tinggalku". Hasil uji t sampel berpasangan selengkapnya terdapat pada Tabel 7.

Tabel 7. Hasil uji t untuk data karakter jujur dan peduli

\begin{tabular}{llll}
\hline Karakter & $\mathrm{T}$ & $\mathrm{df}$ & $\begin{array}{l}\text { Sig. } \\
\text { (2-tailed) }\end{array}$ \\
\hline $\begin{array}{l}\text { Jujur dan } \\
\text { Peduli }\end{array}$ & 7,824 & 31 & 0,000 \\
\hline
\end{tabular}

Berdasarkan hasil uji t pada Tabel 7 diperoleh gambaran bahwa nilai signifikansi karakter jujur dan peduli $0,000<0,05$ sehingga $\mathrm{H}_{0}$ ditolak atau terima $\mathrm{H}_{1}$. Hal ini menunjukkan bahwa terdapat perbedaan yang signifikan rerata karakter jujur dan peduli peserta didik sebelum dan sesudah yang mengikuti pembelajaran menggunakan LKPD tematikintegratif berbasis karakter dengan tema "Tempat Tinggalku".

Hasil Respons Peserta Didik Terhadap LKPD Tematik-Integratif Berbasis Karakter

Hasil respons peserta didik terhadap LKPD setelah mengikuti pembelajaran ditunjukkan pada gambar berikut.

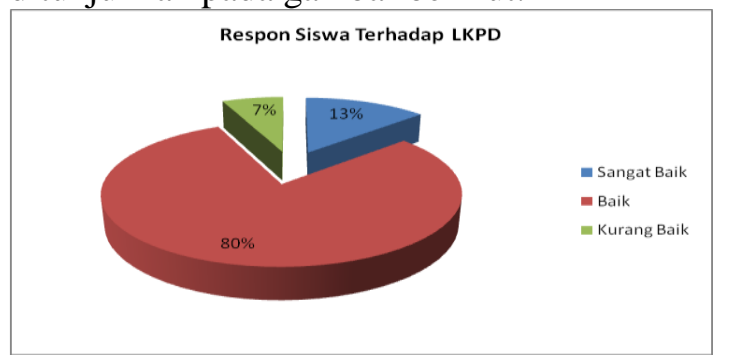

Gambar 1. Hasil respons peserta didik terhadap LKPD pada uji coba lapangan

Berdasarkan hasil respons peserta didik pada uji coba lapangan terlihat bahwa produk LKPD yang dikembangkan, secara umum mendapat respons baik $80 \%$, mendapat respons sangat baik $7 \%$ dan respons kurang baik 13 persen. Hal ini menjunjukan bahwa Sebagian besar peserta didik merespons produk LKPD sudah baik hanya saja beberapa bagian perlu direvisi. Lembar keterlaksanaan pembelajaran digunakan untuk mengetahui keterlaksanaan LKPD tematik-integratif berbasis karakter dalam proses pembelajaran.

Hasil Observasi Keterlaksanaan Pembelajaran
Lembar keterlaksanaan pembelajaran digunakan untuk mengetahui keterlaksanaan LKPD tematik-integratif berbasis karakter dalam proses pembelajaran. Hasil observasi keterlaksanaan pembelajaran pada uji coba lapangan terdapat pada Tabel 8 .

Tabel 8. Persentase keterlaksanaan pembelajaran menggunakan LKPD tematik-integratif Tema "Tempat Tinggalku"

\begin{tabular}{|c|c|c|}
\hline Pertemuan & Skor & Persentase $(\%)$ \\
\hline 1 & 19 & 76 \\
\hline 2 & 21 & 84 \\
\hline 3 & 19 & 76 \\
\hline 4 & 20 & 80 \\
\hline 5 & 20 & 80 \\
\hline 6 & 21 & 84 \\
\hline
\end{tabular}
pembelajaran yang menggunakan LKPD tematik-integratif dengan tema "Tempat Tinggalku" sudah berjalan dengan baik. meskipun ada beberapa kegiatan di dalam LKPD yang belum berjalan secara maksimal.

\section{Hasil Uji Lapangan}

Hasil Observasi Awal dan Akhir Karakter Jujur dan Peduli

Uji lapangan LKPD tematik-integratif dilakukan dengan menggunakan dua kelas yaitu kelas IV A dan kelas IV B. Karakter jujur dan peduli pada kelas eksperimen dan kontrol diamati sebelum dan sesudah mengikuti pembelajaran pada tema "Tempat Tinggalku". Hasil observasi awal dan akhir karakter jujur dan peduli pada kelas eksperimen terdapat pada Tabel 9.

Tabel 9. Hasil observasi awal dan akhir karakter jujur dan peduli

\begin{tabular}{|c|c|c|c|c|c|c|}
\hline \multirow[b]{2}{*}{$\begin{array}{l}\text { Krit } \\
\text { eria }\end{array}$} & \multicolumn{3}{|c|}{ Eksperimen } & \multicolumn{3}{|c|}{ Kontrol } \\
\hline & $\begin{array}{c}\mathrm{Ob} \\
\mathrm{Awl}\end{array}$ & $\begin{array}{c}\mathrm{Ob} \\
\mathrm{Akh}\end{array}$ & Gain & $\begin{array}{l}\text { Ob. } \\
\text { Awl }\end{array}$ & $\begin{array}{c}\text { Ob. } \\
\text { Akh }\end{array}$ & Gain \\
\hline Rata & 62,5 & & & 59,6 & & \\
\hline $\begin{array}{c}\text {-rata } \\
\text { S. }\end{array}$ & 4 & 75,03 & 0,37 & 8 & 67,11 & 0,20 \\
\hline Dev & 3,35 & 5,64 & 0,16 & 4,90 & 5,22 & 0,13 \\
\hline Mak & 69 & 86 & 0,70 & 68 & 80 & 0,5 \\
\hline Min & 57 & 64 & 0,14 & 50 & 59 & 0 \\
\hline
\end{tabular}

Uji Normalitas Data Gain Standar Karakter Jujur dan Peduli

Uji normalitas data gain standar karakter jujur dan peduli dilakukan dengan menggunakan uji Kolmogorov-Smirnov dengan 
taraf signifikansin 0,05 pada kelas eksperien dan kontrol ditunjukkan pada Tabel 10.

Tabel 10. Hasil uji normalitas data gain standart karakter jujur dan peduli

\begin{tabular}{ccrc}
\hline \multirow{2}{*}{ Karakter } & \multirow{2}{*}{ Kelas } & \multicolumn{2}{c}{$\begin{array}{c}\text { Kolmogorov- } \\
\text { Smirnov }\end{array}$} \\
\cline { 3 - 4 } & & Statistic df & Sig. \\
\hline Jujur dan & Eksperimen & 0,11137 & $0,200^{*}$ \\
Peduli & Kontrol & 0,12237 & 0,183 \\
\hline
\end{tabular}

Berdasarkan hasil uji normalitas terlihat bahwa nilai signifikansi data gain karakter jujur dan peduli pada kelas eksperimen yaitu $0,200>0,05$, sehingga $\mathrm{H}_{0}$ diterima. Hal ini menunjukkan bahwa data gain karakter jujur dan peduli pada kelas eksperimen berdistribusi normal. Nilai signifikansi data gain karakter jujur dan peduli pada kelas kontrol yaitu 0,183 $>0,05$, sehingga $\mathrm{H}_{0}$ diterima. Hal ini menunjukkan bahwa data gain karakter jujur dan peduli pada kelas kontrol berdistribusi normal.

\section{Homogenitas Data Gain Standar Karakter Jujur dan Peduli}

Uji homogenitas varians dilakukan terhadap gain karakter jujur dan peduli menggunakan uji Levene dengan taraf signifikansi 5\%. Hasil uji homogenitas gain karakter jujur dan peduli terdapat pada dapat dilihat pada Tabel 11.

Tabel 11. Hasil uji homogenitas gain karakter jujur dan peduli

\begin{tabular}{lrrrr}
\hline Karakter & $\begin{array}{r}\text { Levene } \\
\text { Statistic }\end{array}$ & $d f_{1}$ & $d f_{2}$ & Sig. \\
\hline $\begin{array}{l}\text { Jujur dan } \\
\text { peduli }\end{array}$ & 3,812 & 1 & 72 & 0,055 \\
\hline \multicolumn{5}{c}{ Berdasarkan hasil uji } \\
\hline
\end{tabular}

Tabel 20 terlihat bahwa nilai signifikansi gain karakter jujur dan peduli yaitu 0,055>0,05, sehingga $\mathrm{H}_{0}$ diterima. Hal ini menunjukkan bahwa data gain karakter jujur dan peduli memiliki variansi yang relatif sama/homogen.

\section{Uji t Data Gain Standar Karakter Jujur dan Peduli}

Uji t digunakan untuk membandingkan rata-rata peningkatan karakter jujur dan peduli pada kelas eksperimen dan kelas kontrol. Uji t dilakukan dengan bantuan program SPSS 17 for windows dengan taraf signifikasi 5\%. Kriteria keputusan yang digunakan yaitu tolak $\mathrm{H}_{0}$ jika nilai siginifikansi lebih kecil dari 0,05. Hasil uji t data karakter jujur dan peduli dapat dilihat pada Tabel 12 .

Tabel 12. Hasil uji t data gain karakter jujur dan peduli

\begin{tabular}{cccc}
\hline Karakter & $\mathrm{t}$ & Df & Sig. \\
\hline $\begin{array}{c}\text { Jujur dan } \\
\text { peduli }\end{array}$ & 5,114 & 72 & 0,000 \\
\hline
\end{tabular}

Berdasarkan hasil uji t pada Tabel 12 terlihat bahwa nilai signifikansi gain karakter jujur dan peduli yaitu $0,000<0,05$, sehingga $\mathrm{H}_{0}$ tolak. Terdapat perbedaan yang signifikan rerata peningkatan karakter jujur dan peduli peserta didik yang mengikuti pembelajaran menggunakan LKPD tematik-integratif dengan peserta didik yang mengikuti pembelajaran tanpa menggunkan LKPD tematik-integratif.

\section{Hasil Respons Peserta Didik Terhadap LKPD Tematik Integratif Berbasis Karakter}

Lembar angket respons peserta didik diberikan pada peserta didik kelas IV B (eksperimen) setelah mengikuti pembelajaran menggunakan LKPD tematik-integrati, terdapat pada gambar berikut.

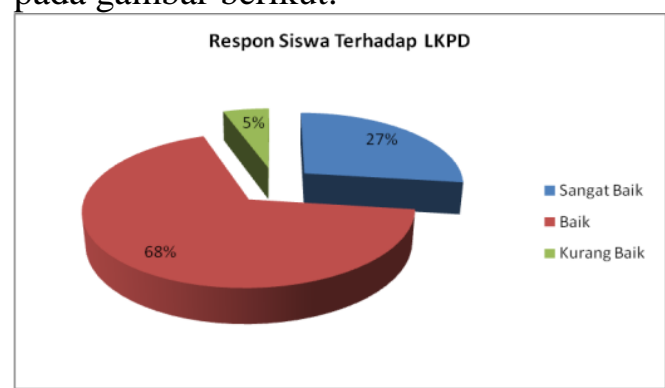

Gambar 2. Hasil respons peserta didik terhadap LKPD pada uji lapangan

Berdasarkan hasil respons peserta didik pada uji lapangan terlihat bahwa produk LKPD yang dikembangkan secara umum mendapat penilaian baik dari peserta didik. Dengan demikian, produk ini layak digunakan secara operasional dalam pembelajaran di kelas.

\section{Hasil Observasi Keterlaksanaan Pembelajaran}

Hasil observasi keterlaksanaan pembelajaran di kelas eksperimen pada uji lapangan terdapat pada Tabel 13. 
Tabel 13. Persentase pelaksanaan pembelajaran menggunakan LKPD tematikintegratif tema "Tempat Tinggalku"

\begin{tabular}{ccc}
\hline Pertemuan & Skor & $\begin{array}{c}\text { Persentase } \\
(\%)\end{array}$ \\
\hline 1 & 23 & 92 \\
2 & 23 & 92 \\
3 & 22 & 88 \\
4 & 23 & 92 \\
5 & 22 & 88 \\
6 & 23 & 92 \\
\hline
\end{tabular}

LKPD tematik-integratif dengan tema "Tempat Tinggalku" sudah berjalan dengan baik sesuai dengan RRP yang dirancang. Beberapa kekurangan dan ketidakmaksimalan pada uji coba lapangan telah diperbaiki dan berjalan dengan baik. Hasil ini menunjukkan bahwa penggunaan LKPD tematik-integratif ini memberikan pengaruh positif terhadap peningkatan karakter peserta didik pada kelas eksperimen yang menggunakan LKPD dibandingkan pada peserta didik di kelas control yang tidak menggunakan LKPD.

\section{Pembahasan Produk Akhir}

Produk akhir dari pengembangan ini adalah LKPD tematik-integratif dengan tema "Tempat Tinggalku" berbasis nilai karakter jujur dan peduli untuk peserta didik kelas IV SD Negeri 2 Tinggarjaya. LKPD ini terdiri atas tiga subtema yaitu subtema "Lingkungan Tempat Tinggalku", "Keunikan Daerah Tempat Tinggalku", "Aku Bangga dengan Daerah Tempat Tinggalku”.

Pengembangan LKPD tematikintegratif berbasis karakter jujur dan peduli telah selesai dikembangkan melalui empat tahapan yakni validasi ahli, temuan uji coba terbatas, temuan uji coba lapangan, dan temuan uji lapangan. Hasil penilaian ahli menunjukkan bahwa LKPD tematik-integratif yang dikembangkan dari segi aspek pengintegrasian karakter, aspek pedagogi, aspek konstruksi menurut ahli karakter, materi dan kurikulum menunjukan kelayakan dengan nilai baik dan LKPD siap untuk diaplikasikan dalam penelitian pada proses uji coba awal. Kelayakan LPKD untuk digunakan terlihat dari aspek isi, bahasa yang mudah di pahami, dan sajian yang menarik.

LKPD tematik-integratif berbasis karakter jujur dan peduli memuat berbagai pengalaman belajar. Hal ini dilandasi dengan teori-teori yang melandasi pembelajaran tematik-integratif salah satunya adalah landasan filosofis yaitu aliran konstruktivisme yang melihat bahwa pengalaman peserta didik secara langsung adalah kunci pembelajaran. Hai ini didukung pula dengan karekteristik peserta didik pada fase operasional konkret bahwa anak-anak mulai menunjukan beberapa pemikiran abstrak meskipun biasanya didefinisikan dengan karakter-karakter atau tindakan-tindakan (Schunk, 2012: 333). Kegiatan di dalam LKPD memacu pengalaman langsung, eksperimen, wawancara, demostrasi, diskusi kelompok, dan mengerjakan soal di dalam LKPD. Oleh karena itu, LKPD dapat membuat peserta didik lebih tertarik untuk belajar, karena setiap soal pada LKPD bertitik tolak pada alam nyata yang sesuai dengan dunia peserta didik, dan karena digunakan model, diagram atau gambar yang sesuai dengan konteks permasalahan

Hal ini diperkuat oleh pendapat Yuldirim, Kurt, \& Ayas (2011: 45) "Thus worksheets are known to help students gain scientific process skills such as setting up experimental mechanism, recording data, interpreting the data, and so on so that they can conceptualize the concepts in their minds. There are several studies showing that worksheets increase students". Pendapat di atas mengandung maksud bahwa lembar kerja dikenal untuk membantu peserta didik memperoleh keterampilan proses ilmiah seperti menyiapkan mekanisme eksperimental, merekam data, menafsirkan data, dan sebagainya sehingga mereka memiliki konsep dalam pikiran mereka. Hal ini sejalan dengan teori pembelajaran konstruktivisme yaitu siswa menciptakan pembelajaran mereka sendiri (Schunk, 2012: 322). Melalui kegiatan-kegiatan tersebut, LKPD dapat memacu peserta didik untuk aktif secara mandiri dan kelompok di sekolah, di rumah dan di lingkungan masyarakat. Peserta didik membangun sendiri pengetahuannya dengan cara guru memberikan kesempatan kepada peserta didik untuk menemukan dan menerapkan hasil pemikiran mereka sendiri.

Hal ini diperkuat oleh hasil penelitian Rakhmawati, Andreas, \& Margareta (2013: 1) yang menunjukkan bahwa penerapan LKPD berbasis karakter berpengaruh terhadap nilai hasil belajar. LKPD dapat meningkatkan hasil belajar peserta didik karena peserta didik 
merasa bahwa LKPD tematik-integratif berbasis karakter lebih menarik dibandingkan LKPD yang sebelumnya digunakan oleh peserta didik. Ketertarikan peserta didik meningkatkan respons untuk lebih giat belajar sehingga mendapatkan hasil belajar yang memuaskan. Hal ini menunjukan bahwa LKPD meningkatkan respons peserta didik di dalam kegiatan pembelajaran.

Respons peserta didik pada uji coba kelompok kecil terhadap LKPD menunjukan bahwa peserta didik merespons baik, namun ada beberapa bagian dari LKPD yang masih perlu direvisi. Respons peserta didik pada uji coba kelompok besar terhadap LKPD menunjukan bahwa peserta didik merespons baik yang lebih tinggi dari uji coba kelompok kecil dengan beberapa revisi di beberapa bagian. Hasil respons peserta didik pada uji lapangan terhadap LKPD menunjukan bahwa peserta didik merespons sangat baik. Dengan demikian, LKPD tematik-integratif berbasis karakter jujur dan peduli produk ini layak digunakan secara operasional dalam pembelajaran di kelas.

LKPD tema "Tempat Tinggalku" ini mengandung karakter jujur dan peduli dimaksudkan agar peserta didik memiliki kepribadian yang jujur dan sikap kepedulian yang tinggi terhadap sesama manusia dan makhluk hidup di lingkungan sekitarnya. Keterlaksanaan pembelajaran menggunakan LKPD tematik-integratif dengan tema "Tempat Tinggalku" pada uji coba kelompok besar dan uji lapangan menunjukkan hasil peningkatan keterlaksanaan pembelajaran menggunakan LKPD. Dengan demikian, keterlaksanaan pembelajaran menggunakan LKPD sudah berjalan dengan baik sesuai RPP dan memberikan pengaruh positif terhadap peningkatan karakter peserta didik.

LKPD tematik-integratif efektif untuk menanamkan karakter jujur dan peduli. Lembar kerja peserta didik berbasis karakter memiliki kelebihan pada tugas inkuiri yang mendorong peserta didik dalam penanaman karakter. Kelebihan ini terlihat dalam setiap tugas yang terdiri dari ecological foundation level, conceptual awarnes level, investigation and evaluation dan environmental action skills level (Dimopoulos, 2009: 335-356). Berdasarkan hasil observasi karakter jujur dan peduli pada kelas eksperimen dan kelas kontrol menunjukkan peningkatan (nilai gain standart) pada kelas eksperimen lebih besar daripada kelas kontrol. Pada hasil uji t terlihat bahwa nilai signifikansi gain karakter jujur dan peduli yaitu $0,000<0,05$, sehingga $\mathrm{H}_{0}$ tolak. Menunjukkan bahwa terdapat perbedaan yang signifikan rerata peningkatan karakter jujur dan peduli peserta didik yang mengikuti pembelajaran menggunakan LKPD tematik integrtif dengan peserta didik yang mengikuti pembelajaran tanpa menggunkan LKPD tematik-integrtif. Hal ini berarti bahwa penggunaan LKPD tematik integratif ini memberikan pengaruh positif terdahap penigkatan karakter peserta didik.

Stedje (2010: 4) berpendapat bahwa "character education occurs each minute in the classroom". Artinya bahwa pendidikan karakter terjadi setiap menit di dalam kelas. Karakter peserta didik akan semakin terbentuk dengan semakin seringnya peserta didik melakukan aktivitas pada LKPD berbasis karakter karena karakter merupakan sifat desposisi seseorang yang relatif stabil. Pendapat di atas diperkuat oleh Schunk (2012: 172) yang menyatakan bahwa Teori permodelan Albert Bandura yang menyatakan bahwa peniruan merupakan perilaku instrumental yang dipelajari karena mengarah pada penguatan. Selain dengan membiasakan peserta didik berprilaku jujur dan peduli, permodelan guru, orang tua dan masyarakat yang mencerminkan kejujuran dan kepedulian akan memberi pengaruh bagi peserta didik untuk mencontoh perilaku tersebut.

LKPD tematik-integratif berbasis karakter yang dikembangkan memiliki kelebihan yang berbeda dengan LKPD lain yakni yang utama adalah berbasis karakter jujur dan peduli, dalam unsur pedagogiknya LKPD tematik-integratif ini memiliki petunjuk belajar dengan kalimat yang jelas dan mudah dipahami, adanya KI dan indikator pembelajaran, informasi pendukung yang berfariasi, singkat dan menarik, terdapat petunjuk kerja atau lembar kerja yang sesuai dengan kegiatan yang akan dilakukan, terdapat lembar puzzel, lembar wawancara, lembar kegiatan individu, lembar kegiatan kelompok, lembar berimajinasi, lembar menggambar, dan lembar mewarnai. Kegiatan LKPD ini mengarahkan dan memicu pada kegiatan yang menarik, demonstrasi, wawancara, berkreasi, berimajinasi, dokumentasi, bertukar pikiran, dan lainnya. LKPD tematik-integratif ini memiliki bagan penguatan karakter pada setiap pertemuan yang berisi simpulan kegiatan pembelajaran dan 
penguatan karakter jujur dan peduli. LKPD tematik-integratif juga berisi bagan kerja sama dengan orang tua yakni peserta didik diharapkan dapat berbagi cerita dan bertukar pikiran mengenai materi yang dipelajarinya di sekolah dengan orang tua di rumah.

LKPD tematik-integratif dalam unsur konstruksi memuat struktur bahasa yang lebih komunikatif, sederhana, pendek, jelas, dan tidak berbelit-belit, LKPD dapat digunakan untuk kegiatan di dalam kelas, di luar kelas, dan di rumah. Kegiatan LKPD tidak hanya berisi soalsoal isian melainkan kegiatan individu dan kegiatan kelompok. LKPD ini juga berisi materi-materi yang akurat dan ringkas

Unsur teknisnya, LKPD tematikintegratif ini menggunakan background berwarna menarik, pendekatannya menggunakan tokoh kartun yang diharapkan dapat membuat peserta didik senang dan termotivasi mengerjakan kegiatan dengan lebih nyaman membaca bacaan dalam LKPD. LKPD tematik-integratif tidak dipadati dengan tulisan, materi dan soal-soal karena halaman yang terlalu padat dengan banyak materi, tulisan, dan soal dapat mengakibatkan peserta didik bosan, monoton, dan sulit memfokuskan perhatian. LKPD memiliki ukuran yang tidak terlalu besar dan kecil sehingga mudah dibawa oleh peserta didik. LKPD tematik-integratif ini dapat dibaca secara jelas dan menarik karena menggunakan kata yang mengajak dengan pewarnaan huruf-huruf yang menarik. LKPD dapat dipahami maknanya oleh peserta didik sehingga memberikan hasil yang optimal pada peserta didik.

Di dalam LKPD ini terdapat 5 kegiatan dengan pendekatan scientific yang cocok dengan pembalajaran sekarang. Temuan dalam uji lapangan mengenai karakter jujur dan peduli sebagai berikut. 1) Karakter jujur terlihat dari meningkatnya kejujuran peserta didik dalam melakukan kegiatan seperti tidak mencontek saat mengerjakan tugas PR, ulangan harian. Peserta didik mengakui kelemahan diri sendiri dan kelebihan teman yang lain. kesadaran sikap jujur pada peserta didik. 2) Karakter peduli terlihat dari meningkatnya rasa kemanusiaan apabila ada teman yang sakit dan mau memberi, meningkatnya rasa kesetiakawanan dengan banyaknya peserta didik yang mau berbagi makanan dan ilmu dengan teman lain, meningkatnya rasa kebersamaan dengan banyaknya peserta didik yang menunjukan sikap tidak membeda-bedakan teman yang satu dengan yang lain serta kompak saat belajar berpasangan dan berkelompok' dan keaktifan peserta didik untuk memelihara tanaman di depan kelas dan di halaman sekolah.

LKPD ini secara khusus membangun dua karakter yang spesifik, yaitu karakter jujur dan peduli. Peserta didik diajak untuk memahami, melakukan, dan membiasakan perilaku jujur dan peduli di dalam kegiatan pembelajaran di sekolah, di rumah dan di lingkungan masyarakat. LKPD ini juga membangun kepedulian peserta didik tidak hanya pada sesama manusia melainkan kepedulian terhadap makhluk hidup dengan tidak merusak lingkungan, menjaga, merawat dan melestarikannya.

\section{PENUTUP}

Berdasarkan hasil penelitian dan hasil kajian produk, yang telah dilakukan dapat disimpulkan bahwa hasil validasi ahli dan praktisi Lembar Kerja Peserta Didik tematikintegratif yang dikembangkan layak digunakan dalam pembelajaran menggunakan Kurikulum 2013 untuk peserta didik kelas IV di SD Negeri 2 Tinggarjaya. Hasil penilaian ahli materi, ahli kurikulum, dan ahli evaluasi menunjukkan bahwa LKPD tematik-integratif yang dikembangkan dari segi aspek pengintegrasian karakter dinilai oleh ahli materi, ahli kurikulum, dan evaluasi mempunyai skor rata-rata 4 dengan kategori "baik". Hasil penilaian LKPD tematik-integratif aspek pedagogik oleh ahli materi, ahli kurikulum, dan ahli evaluasi, menghasilkan skor rat-rata 4,46 dengan kategori "sangat baik". Hasil penilaian LKPD tematikintegratif aspek konstruksi oleh ahli materi, dan ahli kurikulum menghasilkan skor rata-rata yakni 4,49 dengan kriteria "sangat baik". Hasil penilaian LKPD tematik-integratif aspek teknis oleh ahli materi, dan ahli kurikulum menghasilkan skor rat-rata yakni 4,32 dengan kriteria "sangat baik".

Respons peserta didik pada uji lapangan besar terlihat bahwa produk LKPD yang dikembangkan secara umum mendapat respons baik. Dengan demikian produk ini layak digunakan secara operasional dalam pembelajaran di kelas. Respons guru terhadap pengembangan LKPD tematik-integratif berbasis karakter jujur dan peduli pada uji lapangan yakni merespons baik. LKPD sudah 
mencerminkan kegiatan pembelajaran tematikintegratif dengan pendekatan saintific.

LKPD tematik-integratif yang dikembangkan efektif dalam menanamkan karakter jujur dan peduli. Berdasarkan hasil observasi karakter jujur dan peduli pada kelas eksperimen dan kelas kontrol terlihat bahwa peningkatan (nilai gain standard) pada kelas eksperimen lebih besar dari pada kelas kontrol. Pada hasil uji $\mathrm{t}$ terlihat bahwa nilai signifikansi gain karakter jujur dan peduli yaitu $0,000<$ 0,05 , sehingga $\mathrm{H}_{0}$ ditolak. Hal ini menunjukkan bahwa terdapat perbedaan yang signifikan rerata peningkatan karakter jujur dan peduli peserta didik yang mengikuti pembelajaran menggunakan LKPD tematik integrtif dengan peserta didik yang mengikuti pembelajaran tanpa menggunakan LKPD tematik-integratif. Hal ini menunjukkan bahwa penggunaan LKPD tematik integratif ini memberikan pengaruh positif terdahap peningkatan karakter peserta didik.

Adapun saran pemanfaatan produk LKPD tematik-integratif berbasis karakter jujur dan peduli diharapkan tidak hanya didiseminasikan di SDN 2 Tinggarjaya melainkan melibatkan banyak sekolah untuk diseminasi produk LKPD. Penggunaan LKPD tematik-integratif berbasis karakter dalam melakukan kerja knya yang berkaitan dengan memanfaatkan lingkungan sekitar peserta didik

\section{UCAPAN TERIMA KASIH}

Dengan usaha maksimal, akhirnya tulisan ini dapat terselesaikan dan dapat dimuat pada Jurnal Pendidikan Karakter edisi sekarang ini. Oleh karena itu, pada kesempatan ini penulis mengucapkan terima kasih yang setulustulusnya kepada ketua dewan redaksi JPK (Dr. Marzuki) yang telah banyak membantu demi dimuatnya tulisan ini. Ucapan terima kasih juga disampaikan kepada semua pihak yang telah membantu dalam penyelesaian tulisan ini.

\section{DAFTAR PUSTAKA}

Azwar, S. 2010. Tes prestasi. Yogyakarta: Pustaka Pelajar.

Bao, L. 2006. Theoretical comparisons of average normalized gain calculations.
American Journal Physics, 74 (10), 9171992.

Borg, W.R., \& Gall, M.D. 1983. Educational reseach an introduction. New York: Longman.

Kemendiknas. 2010. Juknis pengembangan bahan ajar SMA. Jakarta: Direktorat Pembinaan Sekolah Dasar.

Dimopoulos, D.I., 2009. Planning educational activities and teaching strategies on constructing a conservation educational module. International Journal of Environmental \& Science Education, 4 (4), 351-364.

Kemendikbud. (2013). Kompetensi dasar sekolah dasar $(S D) /$ madrasah ibtidaiyah (MI).

Lickona, T. 1991. Educating for character how our schools can teach respect and responssibility. New York: Bantam Books.

Padangtoday. (2014). "Kekerasan murid SD, walikota Bukittinggi gelar pertemuan mendadak", (12 Oktober 2014). Diakses tanggal 15 Oktober 2014 dari http://www.padangtoday.com /dibukittinggi-siswa-sd-lakukankekerasan.

Poerwati, L.B., \& Sofan, A. 2013. Kurikulum 2013. Jakarta: PT Prestasi Pustakarya.

Rakhmawati, D., Andreas:B.P., \& Margareta, R. 2013. Pengembangan lembar kerja siswa berbasis karakter materi ekosistem. Unnes Journal Biology Education, 2 (3), 11-23.

Rusman. (2011). Model-model pembelajaran. Jakarta: Rajawali Pers.

Schunk D. L. 2012. Teori-teori pembelajaran (Terjemahan Eva Hamdiah, Ahmad Fajar). Yogyakarta: Pustaka Pelajar.

Stedje, L.B. 2010. Nuts and bolts of character education. Diakses pada tanggal 29 Desember 2014, dari 
www.characterfirst.com/assets/files/chara cter EducationsReport.pdf.

Suharjana. 2012. Kebiasaan berperilaku hidup sehat dan nilai-nilai pendidikan karakter. Jurnal Pendidikan Karakter, 2 (2), 189200.

Tempo. 2014. "Siswa SD memilih mencontek jawaban Ujian Nasional", (20 Mei 2014). Diakses tanggal tanggal 7 Juli 2014 dari http://www.tempo.co/read/news/2014/05/ 20/079578898/Siswa-SD-memilih Menyontek-Jawaban-Ujian-Nasional

Yuldirim, N., Kurt, S., \& Ayas, A. 2011. The Effect Of The Worksheet On Student Achievement In Chemical Equilibrium.
Journal Of Turkish Science Education, 8 (3), 32-44. 